Key Words:

DWPF

Frit development

Retention:

Permanent

\title{
PRELIMINARY FRIT DEVELOPMENT AND MELT RATE TESTING FOR SLUDGE BATCH 6 (SB6)
}

\author{
Co-author: K. M. Fox \\ Co-author: D. H. Miller \\ Co-author: T. B. Edwards
}

JULY 2009

Savannah River National Laboratory

Savannah River Nuclear Solutions

Aiken. SC 29808 


\section{DISCLAIMER}

This work was prepared under an agreement with and funded by the U.S. Government. Neither the U. S. Government or its employees, nor any of its contractors, subcontractors or their employees, makes any express or implied:

1. warranty or assumes any legal liability for the accuracy, completeness, or for the use or results of such use of any information, product, or process disclosed; or

2. representation that such use or results of such use would not infringe privately owned rights; or

3. endorsement or recommendation of any specifically identified commercial product, process, or service.

Any views and opinions of authors expressed in this work do not necessarily state or reflect those of the United States Government, or its contractors, or subcontractors.

Printed in the United States of America

Prepared for

U.S. Department of Energy 
Key Words:

DWPF

Frit development

Retention:

Permanent

\title{
PRELIMINARY FRIT DEVELOPMENT AND MELT RATE TESTING FOR SLUDGE BATCH 6 (SB6)
}

\author{
Co-author: K. M. Fox \\ Co-author: D. H. Miller \\ Co-author: T. B. Edwards
}

JULY 2009

Savannah River National Laboratory

Savannah River Nuclear Solutions

Savannah River Site

Aiken, SC 29808 


\section{REVIEWS AND APPROVALS}

K. M. Fox, Co-author, Process Technology Programs

Date

D. H. Miller, Co-author, Process Technology Programs

Date

T. B. Edwards, Co-author, Applied Computational Engineering and Statistics

Date

D. K. Peeler, Peer Reviewer, Process Technology Programs

Date

C. C. Herman, Manager, Process Technology Programs Group

Date

S. L. Marra, Manager,

Date

Environmental \& Chemical Process Technology Research Programs

J. E. Occhipinti, Manager

Date

Waste Solidification Engineering

- ii - 


\section{TABLE OF CONTENTS}

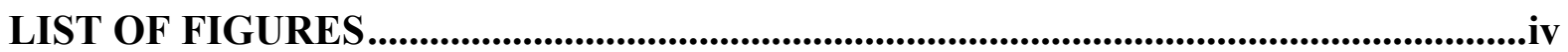

LIST OF TABLES..............................................................................................................................iv

LIST OF ACRONYMS ..........................................................................................................v

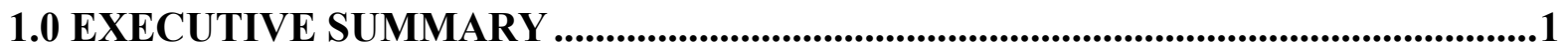

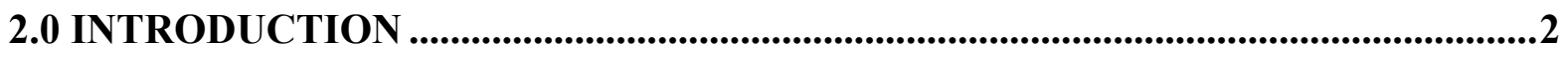

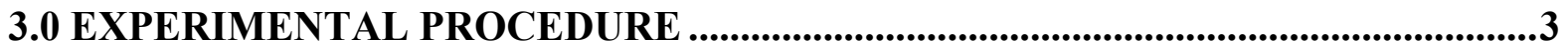

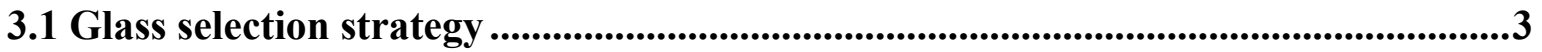

3.2 Glass Fabrication..................................................................................................................7

3.3 Property Measurements .......................................................................................7

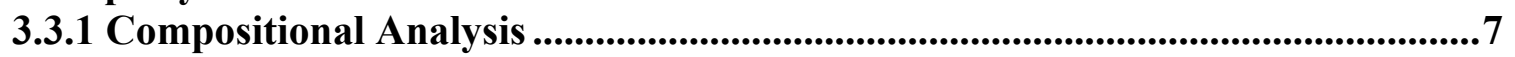

3.3.2 X-Ray Diffraction Analysis ............................................................................................... 7

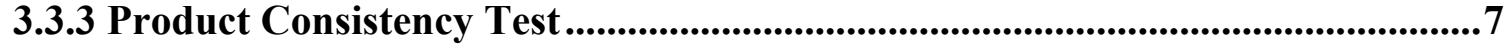

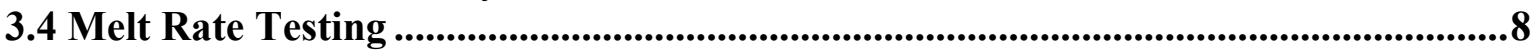

3.4.1 Initial MRF Testing .......................................................................................8

3.4.2 Additional MRF Testing …..........................................................................................8

4.0 RESULTS AND DISCUSSION .................................................................................10

4.1 Chemical Composition Measurements .......................................................................10

4.2 Crystallization..............................................................................................................10

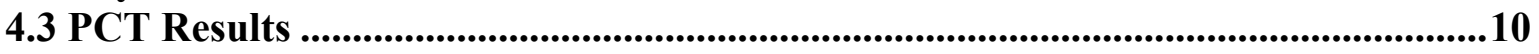

4.4 Initial Melt Rate Results .............................................................................................12

4.5 Additional Melt Rate Results ..........................................................................................13

5.0 CONCLUSIONS ...................................................................................................................15

6.0 PATH FORWARD .........................................................................................................................16

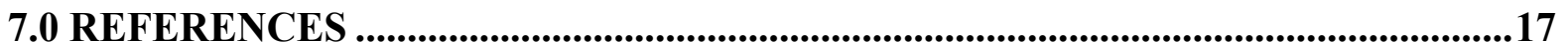

Appendix A...................................................................................................................................19 


\section{LIST OF FIGURES}

Figure 4-1. XRD data for the ccc version of glass SB6R1-04. 10

Figure 4-2. X-ray tomographic image of sample MRF 09-020 (SB6 with Frit 418 at a target of $38 \% \mathrm{WL}$ ).

Figure 4-3. X-ray tomographic image of sample MRF 09-022 (SB6 with Frit 418 at a target of $34 \% \mathrm{WL}$ ).

\section{LIST OF TABLES}

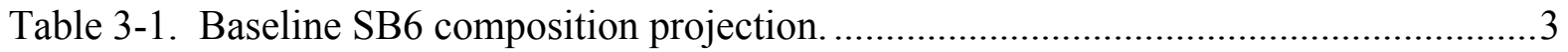

Table 3-2. Compositions of the candidate frits used in this study.........................................

Table 3-3. Summary of glasses selected for study..............................................................

Table 3-4. Target compositions of the study glasses............................................................... 6

Table 3-5. Compositions of the frits selected for MRF testing. ............................................. 8

Table 4-1. PCT results for the study glasses. ...................................................................12

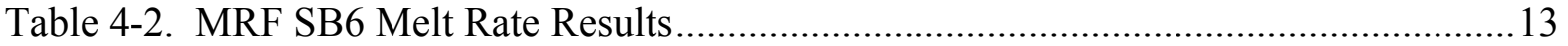

Table 4-3. SB6 melt rate results with SME product (fired 5/20/09). ......................................14 


\section{LIST OF ACRONYMS}

$\begin{array}{ll}\text { ARM } & \text { Approved Reference Material } \\ \text { ARP } & \text { Actinide Removal Process } \\ \text { DWPF } & \text { Defense Waste Processing Facility } \\ \text { EA } & \text { Environmental Assessment } \\ \text { LWO } & \text { Liquid Waste Organization } \\ \text { MAR } & \text { Measurement Acceptability Region } \\ \text { MCU } & \text { Modular Caustic Side Solvent Extraction Unit } \\ \text { MRF } & \text { Melt Rate Furnace } \\ \text { MST } & \text { Monosodium Titanate } \\ \text { PCCS } & \text { Product Composition Control System } \\ \text { PCT } & \text { Product Consistency Test } \\ \text { SB5 } & \text { Sludge Batch 5 } \\ \text { SB6 } & \text { Sludge Batch 6 } \\ \text { SME } & \text { Slurry Mix Evaporator } \\ \text { SRAT } & \text { Sludge Receipt and Adjustment Tank } \\ \text { SRNL } & \text { Savannah River National Laboratory } \\ \text { WL } & \text { Waste Loading }\end{array}$




\subsection{EXECUTIVE SUMMARY}

The Liquid Waste Organization (LWO) provided the Savannah River National Laboratory (SRNL) with a Sludge Batch 6 (SB6) composition projection in March 2009. Based on this projection, frit development efforts were undertaken to gain insight into compositional effects on the predicted and measured properties of the glass waste form and to gain insight into frit components that may lead to improved melt rate for SB6-like compositions.

A series of Sludge Batch 6 (SB6) based glasses was selected, fabricated and characterized in this study to better understand the ability of frit compositions to accommodate uncertainty in the projected SB6 composition. Acceptable glasses (compositions where the Product Composition Control System (PCCS) Measurement Acceptability Region (MAR) predicted acceptable properties, good chemical durability was measured, and no detrimental nepheline crystallization was observed) can be made using Frit 418 with SB6 over a range of $\mathrm{Na}_{2} \mathrm{O}$ and $\mathrm{Al}_{2} \mathrm{O}_{3}$ concentrations. However, the ability to accommodate variation in the sludge composition limits the ability to utilize alternative frits for potential improvements in melt rate. Frit 535, which may offer improvements in melt rate due to its increased $\mathrm{B}_{2} \mathrm{O}_{3}$ concentration, produced acceptable glasses with the baseline SB6 composition at waste loadings of 34 and $42 \%$. However, the PCCS MAR results showed that it is not as robust as Frit 418 in accommodating variation in the sludge composition.

Preliminary melt rate testing was completed in the Melt Rate Furnace (MRF) with four candidate frits for SB6. These four frits were selected to evaluate the impacts of $\mathrm{B}_{2} \mathrm{O}_{3}$ and $\mathrm{Na}_{2} \mathrm{O}$ concentrations in the frit relative to those of Frit 418, although they are not necessarily candidates for SB6 vitrification. Higher concentrations of $\mathrm{B}_{2} \mathrm{O}_{3}$ in the frit relative to that of Frit 418 appeared to improve melt rate. However, when a higher concentration of $\mathrm{B}_{2} \mathrm{O}_{3}$ was coupled with a lower concentration of $\mathrm{Na}_{2} \mathrm{O}$ relative to Frit 418, melt rate did not appear to improve.

It is expected that a SB6 composition projection with less uncertainty will be received during analysis of the Tank 51 E-1 sample, which will be pulled after the completion of aluminum dissolution in August 2009. At that time, additional frit development work will be performed to seek improved melt rates while maintaining viable projected operating windows. This later work will ultimately lead to a frit recommendation for SB6. 


\subsection{INTRODUCTION}

Sludge Batch 6 (SB6) is the next sludge batch to be qualified for processing at the Defense Waste Processing Facility (DWPF). SB6 will consist of the heel of Sludge Batch 5 (SB5) in Tank 51 and portions of material from Tanks 4 and 12. The aluminum dissolution process will be performed on SB6 to reduce the amount of sludge solids that must be processed through the DWPF. Excess plutonium is planned to be added to SB6 from H-Materials Disposition. After washing and preparation of SB6 is completed in Tank 51, it will be transferred to Tank 40 and blended with the approximately 40 inches of SB5 heel. During processing in DWPF, SB6 will be periodically blended with monosodium titanate (MST) and sludge solids from the Actinide Removal Process (ARP) and cesium strip effluent from the Modular Caustic Side Solvent Extraction Unit (MCU).

DWPF has issued a Technical Task Request to address the frit development efforts for SB6, ${ }^{1}$ and SRNL has issued a Task Technical and Quality Assurance Plan in response. ${ }^{2}$ A SB6 composition projection received from the Liquid Waste Organization (LWO) in March 2009, based on the Variation 8 composition proposed by SRNL, ${ }^{3}$ was used as a baseline for this study.

Prior to the processing of a new sludge batch in DWPF, the Savannah River National Laboratory (SRNL) must analyze and confirm that the sludge batch produces an acceptable glass via the Product Composition Control System (PCCS). An integral part of this qualification process is the development of a frit which, when coupled with the sludge, produces an acceptable glass and maximizes waste throughput. The objective of the frit development task is to provide DWPF with technical information from which a business decision can be made in terms of frit selection for SB6. A collection of several key criteria will provide the basis for the frit development and selection process. These include identifying frits that: provide reasonable projected operational windows over the anticipated SB6 composition region, are robust to anticipated sludge composition variation and the addition of ARP and MCU material, meet or exceed waste loading expectations, improve or maintain high melt rates, and have compositions that are feasible for fabrication by the frit vendors.

In this preliminary report, frit compositions are explored that may provide reasonable projected operating windows over a range of SB6 compositions since the constitution of SB6 has not yet been finalized. The frits were evaluated using both model-based assessments and experimental studies to verify that the glasses produced meet all of the processing and product performance constraints. In addition, the melt rate performance of four candidate frits was evaluated using the Melt Rate Furnace (MRF). Additional MRF testing was performed to provide a preliminary look at the impact of waste loading on melt rate for SB6. 


\subsection{EXPERIMENTAL PROCEDURE}

\subsection{GLASS SELECTION STRATEGY}

The two largest compositional uncertainties for SB6 are the $\mathrm{Al}_{2} \mathrm{O}_{3}$ concentration, which is dependent on the effectiveness of the aluminum dissolution and removal process, and the $\mathrm{Na}_{2} \mathrm{O}$ concentration, which is dependent on the degree of sludge washing. SRNL developed a series of SB6 composition scenarios to evaluate the impact of these uncertainties on the ability to select a frit for the production of an acceptable glass waste form.

A SB6 composition projection received from $\mathrm{LWO}^{\mathrm{a}}$ in March 2009, based on the Variation 8 composition proposed by SRNL, ${ }^{3}$ was used as a baseline for this study and is shown in Table 3-1.

Table 3-1. Baseline SB6 composition projection.

\begin{tabular}{|c|c|}
\hline Oxide & (wt \%) \\
\hline $\mathrm{Al}_{2} \mathrm{O}_{3}$ & 23.01 \\
\hline $\mathrm{BaO}$ & 0.16 \\
\hline $\mathrm{CaO}$ & 2.49 \\
\hline $\mathrm{Ce}_{2} \mathrm{O}_{3}$ & 0.14 \\
\hline $\mathrm{Cr}_{2} \mathrm{O}_{3}$ & 0.30 \\
\hline $\mathrm{CuO}$ & 0.08 \\
\hline $\mathrm{Fe}_{2} \mathrm{O}_{3}$ & 24.26 \\
\hline $\mathrm{K}_{2} \mathrm{O}$ & 0.03 \\
\hline $\mathrm{La}_{2} \mathrm{O}_{3}$ & 0.07 \\
\hline $\mathrm{MgO}$ & 1.96 \\
\hline $\mathrm{MnO}$ & 7.04 \\
\hline $\mathrm{Na}_{2} \mathrm{O}$ & 26.65 \\
\hline $\mathrm{NiO}$ & 3.86 \\
\hline $\mathrm{PbO}$ & 0.10 \\
\hline $\mathrm{SO}_{4}{ }^{2-}$ & 0.72 \\
\hline $\mathrm{SiO}_{2}$ & 1.52 \\
\hline $\mathrm{ThO}_{2}$ & 0.91 \\
\hline $\mathrm{TiO}_{2}$ & 0.02 \\
\hline $\mathrm{U}_{3} \mathrm{O}_{8}$ & 6.26 \\
\hline $\mathrm{ZnO}$ & 0.10 \\
\hline $\mathrm{ZrO}_{2}$ & 0.32 \\
\hline
\end{tabular}

Variation was added to the sludge $\mathrm{Al}_{2} \mathrm{O}_{3}$ and $\mathrm{Na}_{2} \mathrm{O}$ concentrations in $1 \mathrm{wt} \%$ increments up to $5 \mathrm{wt} \%$ above and $5 \mathrm{wt} \%$ below the baseline concentrations of each of these two oxides, with the remaining components being normalized to a total of $100 \mathrm{wt} \%$. This process resulted in 121 potential SB6 compositions. Each of these sludge compositions was then combined with Frit 418 and Frit 535 (selected earlier as candidates for preliminary SB6 melt rate studies, ${ }^{4}$ Table 3-2) over waste loadings (WLs) of $25-50 \%$. These glass compositions were evaluated using PCCS Measurement Acceptability Region (MAR) assessments to determine the range of WLs over which an acceptable glass was predicted - termed the projected operating window - for each combination of frit and sludge.

${ }^{\text {a }}$ Composition projection received through email from D.K. Peeler on 3/18/09. Worksheet "SB456_030909_Wash to Var 8 Target.xls" was used to calculate $\mathrm{S}^{2}{ }^{2-}$ concentration for this projection. 
Table 3-2. Compositions of the candidate frits used in this study.

\begin{tabular}{||c|c|c|c|c||}
\hline \multirow{2}{*}{ Frit ID } & \multicolumn{4}{|c||}{ Oxide (wt \%) } \\
\cline { 2 - 5 } & $\mathbf{B}_{\mathbf{2}} \mathbf{O}_{\mathbf{3}}$ & $\mathbf{L i}_{\mathbf{2}} \mathbf{O}$ & $\mathbf{N a}_{\mathbf{2}} \mathbf{O}$ & $\mathbf{S i O}_{\mathbf{2}}$ \\
\hline 418 & 8 & 8 & 8 & 76 \\
\hline 535 & 14 & 7 & 8 & 71 \\
\hline
\end{tabular}

The PCCS MAR outcomes were reviewed to select frit and sludge compositions for experimental testing representing possible SB6 preparation scenarios and reasonable projected operating windows $(25 \%$ to at least $39 \% \mathrm{WL})$. Nine glass compositions were selected, as summarized in Table 3-3 and described as follows:

- Four glasses were selected representing the SB6 baseline composition combined with each of the two frits at waste loadings that would be relatively low (34\%) and relatively high (42\%) for DWPF operation. These are glasses SB6R1-03 through SB6R1-06 in Table 3-3.

- One glass was selected with Frit 418 at 38\% WL (considered a reasonable target for SB6 processing) and a sludge composition having the baseline $\mathrm{Na}_{2} \mathrm{O}$ concentration but a higher $\mathrm{Al}_{2} \mathrm{O}_{3}$ concentration, representing a scenario where the aluminum dissolution process is not as effective as expected. This is glass SB6R1-07 in Table 3-3. Frit 418 alone was used for this and the remaining glasses since the PCCS MAR results showed it to be more robust to compositional variation than Frit 535. That is, the projected operating windows for the various sludge compositions when combined with Frit 418 were generally wider than those with Frit 535.

- Two glass compositions with Frit 418 at $38 \%$ WL were selected at a higher $\mathrm{Na}_{2} \mathrm{O}$ concentration in the sludge, representing less washing of SB6 as compared to the baseline projection. One glass has the baseline $\mathrm{Al}_{2} \mathrm{O}_{3}$ concentration while the other has a higher $\mathrm{Al}_{2} \mathrm{O}_{3}$ concentration, again representing reduced effectiveness of the aluminum dissolution process. These are glasses SB6R1-08 and SB6R1-09 in Table 3-3.

- Two glass compositions with Frit 418 at $38 \%$ WL were selected at a lower $\mathrm{Na}_{2} \mathrm{O}$ concentration in the sludge, representing more washing of SB6 as compared to the baseline projection. One glass has the baseline $\mathrm{Al}_{2} \mathrm{O}_{3}$ concentration while the other has a higher $\mathrm{Al}_{2} \mathrm{O}_{3}$ concentration. These are glasses SB6R1-01 and SB6R1-02 in Table 3-3. 
Table 3-3. Summary of glasses selected for study.

\begin{tabular}{||c|c|c|c|c||}
\hline Glass ID & $\begin{array}{c}\text { Sludge } \mathbf{A l}_{2} \mathbf{O}_{3} \\
(\mathbf{w t ~ \% )}\end{array}$ & $\begin{array}{c}\text { Sludge } \mathbf{N a}_{2} \mathbf{O} \\
(\mathbf{w t} \%)\end{array}$ & Frit ID & WL \\
\hline SB6R1-01 & 23.01 & 23.65 & 418 & 38 \\
\hline SB6R1-02 & 28.01 & 23.65 & 418 & 38 \\
\hline SB6R1-03 & 23.01 & 26.65 & 418 & 34 \\
\hline SB6R1-04 & 23.01 & 26.65 & 418 & 42 \\
\hline SB6R1-05 & 23.01 & 26.65 & 535 & 34 \\
\hline SB6R1-06 & 23.01 & 26.65 & 535 & 42 \\
\hline SB6R1-07 & 28.01 & 26.65 & 418 & 38 \\
\hline SB6R1-08 & 23.01 & 29.65 & 418 & 38 \\
\hline SB6R1-09 & 28.01 & 29.65 & 418 & 38 \\
\hline
\end{tabular}

The target compositions of the nine selected glasses are given in Table 3-4. 
Table 3-4. Target compositions of the study glasses.

\begin{tabular}{|c|c|c|c|c|c|c|c|c|c|}
\hline Oxide & SB6R1-01 & SB6R1-02 & SB6R1-03 & SB6R1-04 & SB6R1-05 & SB6R1-06 & SB6R1-07 & SB6R1-08 & SB6R1-09 \\
\hline $\mathrm{Al}_{2} \mathrm{O}_{3}$ & 8.74 & 10.64 & 7.82 & 9.66 & 7.82 & 9.66 & 10.64 & 8.74 & 10.64 \\
\hline $\mathrm{B}_{2} \mathrm{O}_{3}$ & 4.96 & 4.96 & 5.28 & 4.64 & 9.24 & 8.12 & 4.96 & 4.96 & 4.96 \\
\hline $\mathrm{BaO}$ & 0.06 & 0.06 & 0.05 & 0.07 & 0.05 & 0.07 & 0.05 & 0.06 & 0.05 \\
\hline $\mathrm{CaO}$ & 1.00 & 0.91 & 0.85 & 1.05 & 0.85 & 1.05 & 0.85 & 0.89 & 0.80 \\
\hline $\mathrm{Ce}_{2} \mathrm{O}_{3}$ & 0.06 & 0.05 & 0.05 & 0.06 & 0.05 & 0.06 & 0.05 & 0.05 & 0.04 \\
\hline $\mathrm{Cr}_{2} \mathrm{O}_{3}$ & 0.12 & 0.11 & 0.10 & 0.13 & 0.10 & 0.13 & 0.10 & 0.11 & 0.10 \\
\hline $\mathrm{CuO}$ & 0.03 & 0.03 & 0.03 & 0.03 & 0.03 & 0.03 & 0.03 & 0.03 & 0.03 \\
\hline $\mathrm{Fe}_{2} \mathrm{O}_{3}$ & 9.77 & 8.85 & 8.25 & 10.19 & 8.25 & 10.19 & 8.30 & 8.67 & 7.75 \\
\hline $\mathrm{K}_{2} \mathrm{O}$ & 0.01 & 0.01 & 0.01 & 0.01 & 0.01 & 0.01 & 0.01 & 0.01 & 0.01 \\
\hline $\mathrm{La}_{2} \mathrm{O}_{3}$ & 0.03 & 0.03 & 0.02 & 0.03 & 0.02 & 0.03 & 0.02 & 0.02 & 0.02 \\
\hline $\mathrm{Li}_{2} \mathrm{O}$ & 4.96 & 4.96 & 5.28 & 4.64 & 4.62 & 4.06 & 4.96 & 4.96 & 4.96 \\
\hline $\mathrm{MgO}$ & 0.79 & 0.71 & 0.66 & 0.82 & 0.66 & 0.82 & 0.67 & 0.70 & 0.63 \\
\hline $\mathrm{MnO}$ & 2.83 & 2.57 & 2.39 & 2.96 & 2.39 & 2.96 & 2.41 & 2.52 & 2.25 \\
\hline $\mathrm{Na}_{2} \mathrm{O}$ & 13.95 & 13.95 & 14.34 & 15.83 & 14.34 & 15.83 & 15.09 & 16.23 & 16.23 \\
\hline $\mathrm{NiO}$ & 1.55 & 1.41 & 1.31 & 1.62 & 1.31 & 1.62 & 1.32 & 1.38 & 1.23 \\
\hline $\mathrm{PbO}$ & 0.04 & 0.04 & 0.03 & 0.04 & 0.03 & 0.04 & 0.03 & 0.04 & 0.03 \\
\hline $\mathrm{SO}_{4}^{2-}$ & 0.29 & 0.26 & 0.24 & 0.30 & 0.24 & 0.30 & 0.25 & 0.26 & 0.23 \\
\hline $\mathrm{SiO}_{2}$ & 47.73 & 47.67 & 50.68 & 44.72 & 47.38 & 41.82 & 47.64 & 47.66 & 47.61 \\
\hline $\mathrm{ThO}_{2}$ & 0.37 & 0.33 & 0.31 & 0.38 & 0.31 & 0.38 & 0.31 & 0.33 & 0.29 \\
\hline $\mathrm{TiO}_{2}$ & 0.01 & 0.01 & 0.01 & 0.01 & 0.01 & 0.01 & 0.01 & 0.01 & 0.01 \\
\hline $\mathrm{U}_{3} \mathrm{O}_{8}$ & 2.52 & 2.29 & 2.13 & 2.63 & 2.13 & 2.63 & 2.14 & 2.24 & 2.00 \\
\hline $\mathrm{ZnO}$ & 0.04 & 0.04 & 0.03 & 0.04 & 0.03 & 0.04 & 0.03 & 0.04 & 0.03 \\
\hline $\mathrm{ZrO}_{2}$ & 0.13 & 0.12 & 0.11 & 0.13 & 0.11 & 0.13 & 0.11 & 0.11 & 0.10 \\
\hline
\end{tabular}




\subsection{GLASS FABRICATION}

Although specific frit compositions and sludge recipes were used for the PCCS evaluations, each of the study glasses was prepared from the proper proportions of reagent-grade metal oxides, carbonates, and boric acid in $150 \mathrm{~g}$ batches. ${ }^{5}$ The raw materials were thoroughly mixed and placed into platinum/gold, $250 \mathrm{ml}$ crucibles. The batch was placed into a high-temperature furnace at the target melt temperature of $1150{ }^{\circ} \mathrm{C} .{ }^{6}$ The crucible was removed from the furnace after an isothermal hold at the melt temperature for 1 hour. The glass was poured onto a clean, stainless steel plate and allowed to air cool (quench). The glass pour patty was used as a sampling stock for the various property measurements, including chemical composition and durability testing.

Approximately $25 \mathrm{~g}$ of each glass was heat-treated to simulate cooling along the centerline of a DWPF-type canister ${ }^{7}$ to gauge the effects of thermal history on the product performance. This cooling schedule is referred to as the centerline canister cooling ( $\mathrm{ccc}$ ) heat treatment. Visual observations of both quenched and ccc glasses were documented.

\subsection{PROPERTY MEASUREMENTS}

\subsubsection{Compositional Analysis}

To confirm that the as-fabricated glasses met the target compositions, a representative sample from each quenched glass was submitted to SRNL Analytical Development (AD) for chemical analysis. Two dissolution techniques, sodium peroxide fusion (PF) and lithium-metaborate fusion (LM), were used to prepare the glass samples for analysis. Each of the samples was analyzed by Inductively Coupled Plasma - Atomic Emission Spectroscopy (ICP-AES). Glass standards were also intermittently measured to assess the performance of the ICP-AES instrument over the course of these analyses. Note that $\mathrm{ThO}_{2}$ was not included in the analyses despite having been included in the glasses. This will not impact the outcome of the study as the target concentrations of $\mathrm{ThO}_{2}$ in the glasses are small.

\subsubsection{X-Ray Diffraction Analysis}

Representative samples of each quenched and ccc glass were submitted to AD for X-ray diffraction (XRD) analysis. Samples were run under conditions providing a detection limit of approximately $0.5 \mathrm{vol} \%$. That is, if crystals (or unincorporated batch material) were present at $0.5 \mathrm{vol} \%$ or greater, the diffractometer would not only be capable of detecting the crystals but would also allow a qualitative determination of the type of crystal(s) present. Otherwise, a characteristically high background signal (amorphous hump) devoid of crystalline spectral peaks indicates that the glass product is free of crystallization, suggesting either a completely amorphous product or that the degree of crystallization is below the detection limit.

\subsubsection{Product Consistency Test}

The Product Consistency Test (PCT) Method- $\mathrm{A}^{8}$ was performed in triplicate on each quenched and ccc glass to assess chemical durability. Also included in the experimental test matrix was the Environmental Assessment (EA) benchmark glass, ${ }^{9}$ the Approved Reference Material (ARM) glass, and blanks from the sample cleaning batch. Samples were ground, washed, and prepared according to the standard procedure. ${ }^{8}$ Fifteen milliliters of Type-I ASTM water were added to $1.5 \mathrm{~g}$ of glass in stainless steel vessels. The vessels were closed, sealed, and placed in an oven at $90 \pm 2{ }^{\circ} \mathrm{C}$ where the samples were maintained at temperature for 7 days. Once cooled, the resulting solutions were sampled (filtered and acidified), then labeled and analyzed by AD. Normalized release rates were calculated based on the target and measured compositions using the average of the common logarithms of the leachate concentrations. 


\subsection{MELT RATE TESTING}

The Melt Rate Furnace (MRF) is utilized to compare the melting behavior of different feed formulations for the DWPF. The furnace inner chamber is cylindrical, approximately $18 \mathrm{~cm}$ in diameter and $14 \mathrm{~L}$ in volume, with heating coils winding around the chamber walls. Samples are prepared by mixing simulated Sludge Receipt and Adjustment Tank (SRAT) product with frit in the proper ratio to obtain the desired waste loading. The material is dried and then screened through a 10 mesh sieve before being poured into a $1200 \mathrm{~mL}$ stainless steel beaker. The beaker is placed in an insulating sleeve and covered with a vented, insulating cover. The furnace is heated to approximately $1150^{\circ} \mathrm{C}$ with the top opening covered. Once the furnace reaches the set point, the cover is removed and the beaker containing sufficient product to produce $525 \mathrm{~g}$ of glass is inserted. When inserted, the beaker bottom is approximately flush with the top of the uppermost heating coil. After 50 minutes, the beaker is removed from the furnace. There is a twenty minute period between successive tests to allow the furnace to return to a stable temperature. A beaker containing a Frit 418 standard is fired along with each series of test beakers. After cooling, the beaker is sectioned and the linear melt rate determined by measuring the height of glass formed along the bottom of the beaker. The same procedure is used for measuring the Frit 418 standards.

\subsubsection{Initial MRF Testing}

Four frits were selected for initial MRF testing, with the selection process being described in a previous report. ${ }^{4}$ These frits were selected to evaluate the impacts of $\mathrm{B}_{2} \mathrm{O}_{3}$ and $\mathrm{Na}_{2} \mathrm{O}$ concentrations in the frit relative to those of Frit 418 (although they are not necessarily candidates for SB6 vitrification). The frit compositions are given in Table 3-5. The SRAT product used for this initial testing was designated 09-SB6-7, and its preparation and characterization are described in a separate document. ${ }^{10}$

Table 3-5. Compositions of the frits selected for MRF testing.

\begin{tabular}{||c|c|c|c|c||}
\hline \multirow{2}{*}{ Frit ID } & \multicolumn{4}{|c||}{ Oxide (wt \%) } \\
\cline { 2 - 5 } & $\mathbf{B}_{\mathbf{2}} \mathbf{O}_{\mathbf{3}}$ & $\mathbf{L i}_{\mathbf{2}} \mathbf{O}$ & $\mathbf{N a}_{\mathbf{2}} \mathbf{O}$ & $\mathbf{S i O}_{\mathbf{2}}$ \\
\hline 418 & 8 & 8 & 8 & 76 \\
\hline 535 & 14 & 7 & 8 & 71 \\
\hline 552 & 14 & 7 & 4 & 75 \\
\hline 553 & 8 & 8 & 4 & 80 \\
\hline
\end{tabular}

A WL of 38\% was chosen for this testing to reflect conditions anticipated for SB6 processing in the DWPF. Standard MRF operating procedures were followed to conduct the melt rate testing. ${ }^{11}$ Replicates were used and the beakers were fired in a random order over a period of two days. New refractory felt liners were used for each beaker to ensure consistency. Data sheets are recorded in laboratory notebook SRNL-NB-2009-00077.

\subsubsection{Additional MRF Testing}

After the initial testing, a second series of experiments was conducted to gain preliminary information about the impact of waste loading on melt rate for the SB6 system with Frit 418. Since there was no SRAT product left from the original campaign, it was decided to use some available SB6 Slurry Mix Evaporator (SME) product that contained Frit 418 at a target of 38\% WL. Four separate SRAT batches had been produced to test the effect of acid stoichiometry during sludge processing. These batches were designated SB6-1 through SB6-4 and the details of

their fabrication can be found in a separate report. ${ }^{12}$ The resulting SME products produced from 
the four SRAT batches were blended together to homogenize the material and then separated again into four batches prior to use in MRF testing. An additional amount of Frit 418 was added to two of the batches to target $34 \% \mathrm{WL}$, to gain insight into the effect of waste loading on melt rate.

Since the available SME product contained mercury, the MRF batches required drying in an oven with a vented exhaust that was smaller than the oven used for the first series of MRF tests. In addition, a carbon bed filter system was placed over the MRF exhaust during firing. A previously developed combination of X-ray tomography and imaging software was used to provide for measurement of glass height after firing since possible mercury exposure prevented the beakers from being sectioned in the usual fashion. 


\subsection{RESULTS AND DISCUSSION}

\subsection{CHEMICAL COMPOSITION MEASUREMENTS}

Chemical composition data were received from $\mathrm{AD}$ as cation weight percents and were converted to oxides by multiplying by the appropriate gravimetric factors. A sum of oxides was also computed for each glass. These data are provided in Table A-1 of Appendix A. Included for comparison are the target oxide concentrations, the difference in weight percent between the target and measured values, and the percent difference between the target and measured values. In general, the results indicate only minor difficulties in meeting the target concentration for each oxide for each glass, none of which should impact the performance of the glasses or the outcome of the study. Some larger percent errors are present for some of the minor oxides, although this will not impact the outcome of the study due to their low concentrations.

\subsection{CRYSTALLIZATION}

Most of the quenched glasses were free of any visible crystallization. Glasses SB6R1-04 and SB6R1-06 had small amounts of crystallization visible on the surface but no crystallization visible in the interior or bulk of the samples. After the ccc heat treatment, each of the glasses had crystallization visible on the surface but the bulk of the glasses were free of visible crystallization. XRD results showed that the quenched glasses were free of any detectable crystallization. Small amounts of trevorite $\left(\mathrm{NiFe}_{2} \mathrm{O}_{4}\right)$, a spinel that is not expected to impact glass durability ${ }^{13}$, were identified in three of the ccc glasses, SB6R1-02, SB6R1-04 and SB6R1-06. A representative XRD plot for the ccc version of glass SB6R1-04 is shown in Figure 4-1. Overall, the XRD results indicate no crystallization or inhomogeneity that would impact the durability performance of the glasses.

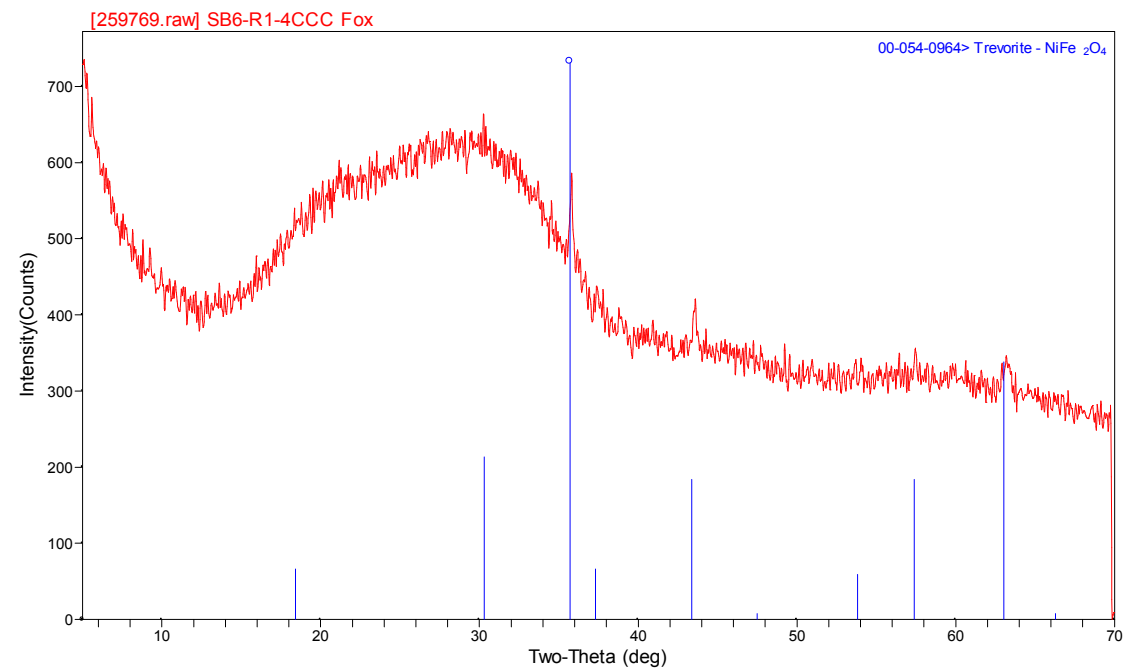

Figure 4-1. XRD data for the cce version of glass SB6R1-04.

\subsection{PCT RESULTS}

The normalized leachate (NL) values for each of the study glasses are summarized by heat treatment and compositional view in Table 4-1. The values for the ARM glass fall within the control bands, ${ }^{14}$ indicating that the PCTs were performed correctly. The NL values for the EA glass fall below the reference values (e.g., the reference value for NL [B] for the EA glass is 
$16.695 \mathrm{~g} / \mathrm{L}) .{ }^{9}$ However, the tested glasses were still an order of magnitude below the measured releases for EA and this discrepancy will not impact the outcome of the study. Note that in two cases, the quenched version of glass SB6R1-01 and the ccc version of glass SB6R1-08, one of the triplicate PCT vessels had a volume to mass ratio that was outside the limits dictated by the ASTM standard. In these cases, this one triplicate value was removed and only the two remaining measurements were used in further calculations. There were no solution weight loss issues for any of the test vessels. The concentrations of the analytes of interest in the blanks were all below detection limits, and therefore no blank correction was performed.

Although duplicate measurements were obtained for some of the samples, all of the SB6R1-series glasses had a NL [B] value that was more than an order of magnitude below that of the EA benchmark, ${ }^{9}$ regardless of heat treatment or compositional view. These results indicate that all of the frit and sludge combinations tested here are sufficiently durable for repository acceptance. 
Table 4-1. PCT results for the study glasses.

\begin{tabular}{|c|c|c|c|c|c|c|}
\hline Glass ID & $\begin{array}{c}\text { Heat } \\
\text { Treatment }\end{array}$ & $\begin{array}{c}\text { Composition } \\
\text { View }\end{array}$ & $\begin{array}{c}\text { NL [B] } \\
(\mathrm{g} / \mathrm{L})\end{array}$ & $\begin{array}{c}\text { NL [Li] } \\
(\mathbf{g} / \mathbf{L})\end{array}$ & $\begin{array}{c}\text { NL [Na] } \\
(\mathrm{g} / \mathbf{L})\end{array}$ & $\begin{array}{c}\text { NL [Si] } \\
(\mathrm{g} / \mathrm{L})\end{array}$ \\
\hline ARM & - & reference & 0.49 & 0.59 & 0.52 & 0.28 \\
\hline EA & - & reference & 13.37 & 7.96 & 10.77 & 3.39 \\
\hline SB6R1-1 & quenched & target & 0.74 & 0.80 & 0.94 & 0.51 \\
\hline SB6R1-2 & quenched & target & 0.68 & 0.74 & 0.87 & 0.47 \\
\hline SB6R1-3 & quenched & target & 0.77 & 0.88 & 1.05 & 0.55 \\
\hline SB6R1-4 & quenched & target & 0.91 & 0.86 & 1.17 & 0.58 \\
\hline SB6R1-5 & quenched & target & 0.80 & 0.77 & 0.85 & 0.47 \\
\hline SB6R1-6 & quenched & target & 0.85 & 0.75 & 0.97 & 0.49 \\
\hline SB6R1-7 & quenched & target & 0.67 & 0.70 & 0.90 & 0.48 \\
\hline SB6R1-8 & quenched & target & 0.87 & 0.95 & 1.25 & 0.61 \\
\hline SB6R1-9 & quenched & target & 0.74 & 0.78 & 1.10 & 0.54 \\
\hline SB6R1-1 & $\mathrm{ccc}$ & target & 0.78 & 0.87 & 0.91 & 0.52 \\
\hline SB6R1-2 & ccc & target & 0.66 & 0.74 & 0.81 & 0.47 \\
\hline SB6R1-3 & $\mathrm{ccc}$ & target & 0.77 & 0.90 & 0.96 & 0.55 \\
\hline SB6R1-4 & ccc & target & 0.87 & 0.92 & 1.08 & 0.58 \\
\hline SB6R1-5 & $\mathrm{ccc}$ & target & 0.71 & 0.70 & 0.75 & 0.44 \\
\hline SB6R1-6 & $\mathrm{ccc}$ & target & 0.89 & 0.82 & 0.95 & 0.50 \\
\hline SB6R1-7 & ccc & target & 0.68 & 0.76 & 0.88 & 0.49 \\
\hline SB6R1-8 & $\mathrm{ccc}$ & target & 0.84 & 0.93 & 1.11 & 0.58 \\
\hline SB6R1-9 & ccc & target & 0.75 & 0.84 & 1.04 & 0.55 \\
\hline SB6R1-1 & quenched & measured & 0.78 & 0.81 & 0.91 & 0.53 \\
\hline SB6R1-2 & quenched & measured & 0.71 & 0.78 & 0.85 & 0.50 \\
\hline SB6R1-3 & quenched & measured & 0.85 & 0.90 & 1.03 & 0.58 \\
\hline SB6R1-4 & quenched & measured & 0.99 & 0.90 & 1.14 & 0.62 \\
\hline SB6R1-5 & quenched & measured & 0.86 & 0.80 & 0.86 & 0.49 \\
\hline SB6R1-6 & quenched & measured & 0.88 & 0.76 & 0.95 & 0.51 \\
\hline SB6R1-7 & quenched & measured & 0.72 & 0.73 & 0.90 & 0.51 \\
\hline SB6R1-8 & quenched & measured & 0.93 & 0.96 & 1.23 & 0.64 \\
\hline SB6R1-9 & quenched & measured & 0.78 & 0.79 & 1.05 & 0.57 \\
\hline SB6R1-1 & $\mathrm{ccc}$ & measured & 0.81 & 0.89 & 0.88 & 0.54 \\
\hline SB6R1-2 & $\mathrm{ccc}$ & measured & 0.69 & 0.78 & 0.79 & 0.50 \\
\hline SB6R1-3 & $\mathrm{ccc}$ & measured & 0.84 & 0.92 & 0.95 & 0.58 \\
\hline SB6R1-4 & ccc & measured & 0.95 & 0.95 & 1.05 & 0.62 \\
\hline SB6R1-5 & $\mathrm{ccc}$ & measured & 0.76 & 0.72 & 0.76 & 0.47 \\
\hline SB6R1-6 & ccc & measured & 0.92 & 0.83 & 0.93 & 0.53 \\
\hline SB6R1-7 & $\mathrm{ccc}$ & measured & 0.73 & 0.80 & 0.88 & 0.53 \\
\hline SB6R1-8 & $\mathrm{ccc}$ & measured & 0.90 & 0.93 & 1.09 & 0.61 \\
\hline SB6R1-9 & $\mathrm{ccc}$ & measured & 0.80 & 0.85 & 0.99 & 0.58 \\
\hline
\end{tabular}

\subsection{INITIAL MELT RATE RESULTS}

The initial MRF testing took place over two days to accommodate all of the replicates. As seen in Table 4-2, the results indicated that Frit 535 consistently produced the highest melt rate with the SB6 SRAT material. Frit 535 contains the maximum concentrations of $\mathrm{B}_{2} \mathrm{O}_{3}$ and $\mathrm{Na}_{2} \mathrm{O}$ used in the testing. Frit 418 produced the second highest melt rate, which suggests that a minimum $\mathrm{Na}_{2} \mathrm{O}$ concentration is required for $\mathrm{B}_{2} \mathrm{O}_{3}$ to be effective at improving melt rate for the SB6 
system. The overall melt rates for all the frits tested in this series were lower than previous testing with SB5, but some similar patterns occur with respect to total alkali. ${ }^{15,16}$

Table 4-2. MRF SB6 Melt Rate Results

(Individual results, fired 4/14/09)

\begin{tabular}{||c|c|c|c|c|c|c|c||}
\hline Run Number & $\begin{array}{c}\text { MRF } \\
\mathbf{0 9 - 0 1 6}\end{array}$ & $\begin{array}{c}\text { MRF } \\
\mathbf{0 9 - 0 1 4}\end{array}$ & $\begin{array}{c}\text { MRF } \\
\mathbf{0 9 - 0 1 0}\end{array}$ & $\begin{array}{c}\text { MRF } \\
\mathbf{0 9 - 0 1 2}\end{array}$ & $\begin{array}{c}\text { MRF } \\
\mathbf{0 9 - 0 1 1}\end{array}$ & $\begin{array}{c}\text { Frit Std } \\
\text { A }\end{array}$ & $\begin{array}{c}\text { Frit Std } \\
\text { B }\end{array}$ \\
\hline Frit & 552 & 418 & 418 & 552 & 535 & - & - \\
\hline Firing Order & 5 & 6 & 2 & 3 & 4 & 1 & 7 \\
\hline $\begin{array}{c}\text { Melt Rate } \\
\text { (in/hr) }\end{array}$ & 0.2 & 0.33 & 0.33 & 0.26 & 0.44 & 1.75 & 1.77 \\
\hline
\end{tabular}

(Individual results, fired 4/15/09)

\begin{tabular}{|c|c|c|c|c|c|c||}
\hline $\begin{array}{c}\text { RUN } \\
\text { NUMBER }\end{array}$ & $\begin{array}{c}\text { MRF } \\
09-013\end{array}$ & $\begin{array}{c}\text { MRF- } \\
09-019\end{array}$ & $\begin{array}{c}\text { MRF } \\
09-015\end{array}$ & $\begin{array}{c}\text { MRF } \\
09-018\end{array}$ & $\begin{array}{c}\text { MRF } \\
09-017\end{array}$ & $\begin{array}{c}\text { FRIT } \\
\text { STD }\end{array}$ \\
\hline FRIT & $\mathbf{5 5 3}$ & $\mathbf{5 3 5}$ & $\mathbf{5 3 5}$ & $\mathbf{4 1 8}$ & $\mathbf{5 5 3}$ & - \\
\hline $\begin{array}{c}\text { FIRING } \\
\text { ORDER }\end{array}$ & $\mathbf{3}$ & $\mathbf{6}$ & $\mathbf{2}$ & $\mathbf{4}$ & $\mathbf{5}$ & $\mathbf{1}$ \\
\hline $\begin{array}{c}\text { MELT RATE } \\
\text { (IN/HR) }\end{array}$ & $\mathbf{0 . 2 3}$ & $\mathbf{0 . 4 4}$ & $\mathbf{0 . 3 7}$ & $\mathbf{0 . 2 8}$ & $\mathbf{0 . 1 8}$ & $\mathbf{1 . 6 8}$ \\
$\qquad$ \\
$\qquad \begin{array}{c}\text { FRIT ID } \\
\begin{array}{c}\text { AVG MELT } \\
\text { RATE } \\
\text { (IN/HR) }\end{array}\end{array}$ & $\mathbf{0 . 3 1}$ & $\mathbf{0 . 4 2}$ & $\mathbf{0 . 2 3}$ & $\mathbf{0 . 2 1}$ \\
\hline
\end{tabular}

\subsection{ADDITIONAL MELT RATE RESULTS}

The set of MRF experiments using SB6 SME product yielded overall lower melt rates than were found in the initial testing with SB6 SRAT product. Table 4-3 gives melt rates as calculated by the image analysis software that uses differences in density (as measured by X-ray tomography) to estimate the height of the molten glass. The values for the frit standard are similar to those measured in the MRF testing with SB6 SRAT material (see Table 4-2), indicating that the two measurement methods (manual measurement of sectioned beakers and X-ray tomography image analysis) yield similar results. Figure 4-2 and Figure 4-3 show example section images generated by the software for two of the test beakers. A check of the chemical analysis on the SME products after MRF testing indicated that the waste loading was actually closer to $35 \%$, versus the target of $38 \%$. The addition of Frit 418 to the SME product would then have reduced the second set of beakers to $\sim 31.5 \% \mathrm{WL}$, versus the target of $34 \%$. This does not allow for the desired direct comparison between the two sets of Frit 418 data at 38\% (one using SRAT product and one using SME product). The similar melt rate (approximately $0.3 \mathrm{in} / \mathrm{hr}$ ) between the initial testing at $38 \% \mathrm{WL}$ and the additional testing with SME product at 31.5\% WL makes developing definitive conclusions on the effect of waste loading difficult without further testing. No obvious differences in composition are evident since the SRAT and SME product used in testing were both made using the same sludge (SB6-A). ${ }^{12}$ When comparing the MRF data from the SB6 SME feeds alone (Table 4-3), it appears that decreasing waste loading from $35 \%$ to $31.5 \%$ increases melt rate. 
Table 4-3. SB6 melt rate results with SME product (fired 5/20/09).

\begin{tabular}{||c|c|c|c||}
\hline $\begin{array}{c}\text { RUN } \\
\text { NUMBER }\end{array}$ & FRIT & $\begin{array}{c}\text { TARGET/ACTUAL } \\
\text { WL }(\%)\end{array}$ & $\begin{array}{c}\text { MELT } \\
\text { RATE } \\
(\text { IN/HR })\end{array}$ \\
\hline FRIT STD. & $\mathbf{4 1 8}$ & - & $\mathbf{1 . 6 2}$ \\
\hline MRF -09-020 & $\mathbf{4 1 8}$ & $\mathbf{3 8 . 0 / 3 5 . 0}$ & $\mathbf{0 . 1 7}$ \\
\hline MRF -09-021 & $\mathbf{4 1 8}$ & $\mathbf{3 8 . 0 / 3 5 . 0}$ & $\mathbf{0 . 2 0}$ \\
\hline MRF -09-022 & $\mathbf{4 1 8}$ & $\mathbf{3 4 . 0 / 3 1 . 5}$ & $\mathbf{0 . 3 2}$ \\
\hline MRF -09-023 & $\mathbf{4 1 8}$ & $\mathbf{3 4 . 0 / 3 1 . 5}$ & $\mathbf{0 . 3 5}$ \\
\hline
\end{tabular}

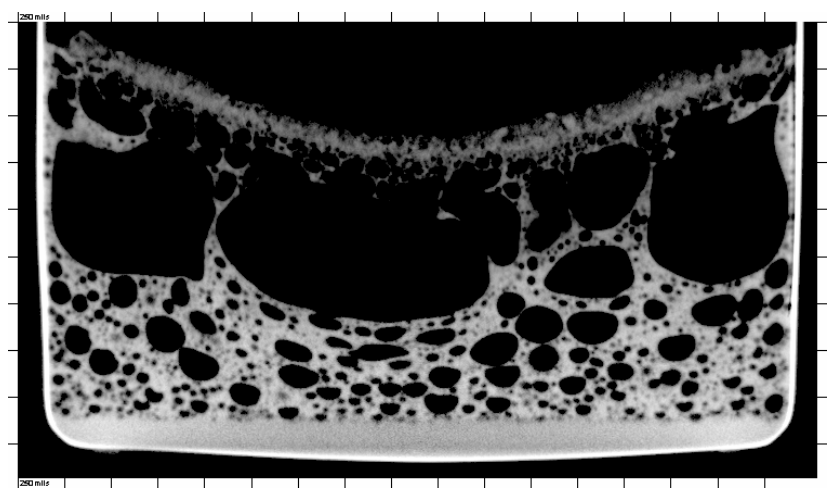

Figure 4-2. X-ray tomographic image of sample MRF 09-020 (SB6 with Frit 418 at a target of $38 \%$ WL).

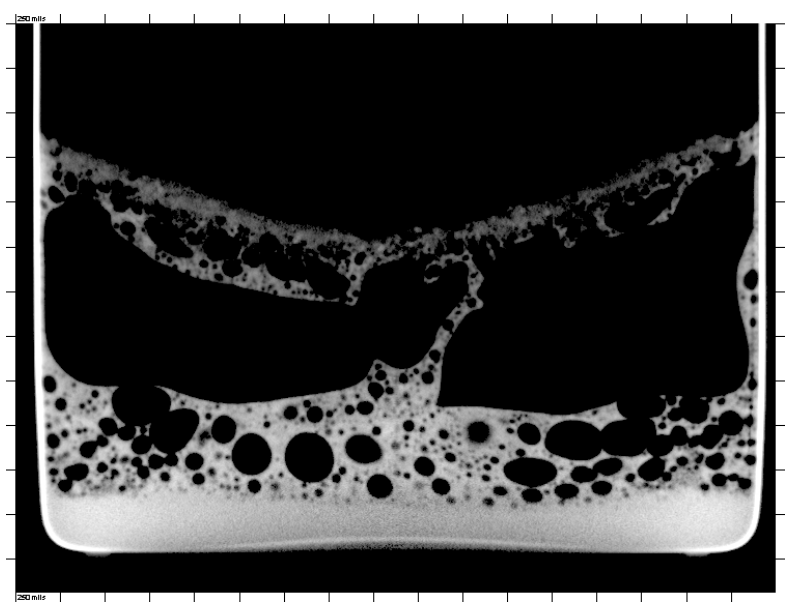

Figure 4-3. X-ray tomographic image of sample MRF 09-022 (SB6 with Frit 418 at a target of $34 \%$ WL). 


\subsection{CONCLUSIONS}

A series of SB6-based glasses was selected, fabricated and characterized in this study to better understand the ability of frit compositions to accommodate uncertainty in the projected SB6 composition. Acceptable glasses (compositions where the PCCS MAR predicted acceptable properties, good chemical durability was measured, and no detrimental nepheline crystallization was observed) can be made using Frit 418 with SB6 over a range of $\mathrm{Na}_{2} \mathrm{O}$ and $\mathrm{Al}_{2} \mathrm{O}_{3}$ concentrations. However, the ability to accommodate variation in the sludge composition limits the ability to target alternative frits for potential improvements in melt rate. Frit 535, which may offer improvements in melt rate due to its increased $\mathrm{B}_{2} \mathrm{O}_{3}$ concentration, produced acceptable glasses with the baseline SB6 composition at waste loadings of 34 and $42 \%$, although the PCCS MAR results showed that it is not as robust as Frit 418 in accommodating variation in the sludge composition.

Preliminary melt rate testing was completed in the MRF with four candidate frits for SB6, again based on early projections of the SB6 composition. Higher concentrations of $\mathrm{B}_{2} \mathrm{O}_{3}$ in the frit relative to that of Frit 418 appeared to improve melt rate. However, when a higher concentration of $\mathrm{B}_{2} \mathrm{O}_{3}$ was coupled with a lower concentration of $\mathrm{Na}_{2} \mathrm{O}$ relative to Frit 418 , melt rate did not appear to improve. Overall the initial testing indicates a reduced melt rate as measured in the MRF compared to the SB5 system with Frit 418. Direct comparisons of MRF data between different sludge systems may not be accurate; it's best to use the data only for comparing the impact of various frit compositions on a single sludge type. 


\subsection{PATH FORWARD}

It is expected that a SB6 composition projection with less uncertainty will be received during analysis of the Tank 51 E-1 sample to be pulled in August 2009 after the completion of aluminum dissolution. At that time additional frit development work will be performed to seek improved melt rates while maintaining viable projected operating windows. There should be a good opportunity for further frit optimization if uncertainty in the SB6 composition is indeed reduced and robustness of the frit to variation in the sludge is not as much of a concern.

Specific items that are suggested for further SB6 frit optimization include:

- Further frit optimization based on the updated SB6 composition projection utilizing paper-based assessments

- Perform a Variability Study for SB6

- Complete additional MRF testing with the updated SB6 composition projection

- Conduct a WL series in the MRF for SB6 with selected frits

- Complete SMRF testing on final frit candidates

- Continue repeatability testing in MRF 


\subsection{REFERENCES}

1. Bricker, J. M., “Technical Task Request: Sludge Batch 6 Frit Optimization,” U.S. Department of Energy Report HLW-DWPF-TTR-2009-0002, Revision 0, Washington Savannah River Company, Aiken, SC (2008).

2. Fox, K. M., "Task Technical and Quality Assurance Plan: Sludge Batch 6 Frit Optimization," U.S. Department of Energy Report SRNL-RP-2008-01342, Revision 0, Savannah River National Laboratory, Aiken, SC (2008).

3. Peeler, D. K., T. B. Edwards and K. M. Fox, "The Impact of Compositional Variation on SB6 Projected Operating Windows," U.S. Department of Energy Report SRNL-L3100-2009-00029, Savannah River National Laboratory, Aiken, SC (2009).

4. Fox, K. M. and T. B. Edwards, "Frit Selection for SB6 Melt Rate Furnace Testing," U.S. Department of Energy Report SRNL-L3100-2009-00046, Savannah River National Laboratory, Aiken, SC (2009).

5. SRNL, "Glass Batching," U.S. Department of Energy Report Manual L29, ITS-0001, Westinghouse Savannah River Company, Aiken, SC (2002).

6. SRNL, "Glass Melting," U.S. Department of Energy Report Manual L29, ITS-0003, Westinghouse Savannah River Company, Aiken, SC (2002).

7. Marra, S. L. and C. M. Jantzen, "Characterization of Projected DWPF Glass Heat Treated to Simulate Canister Centerline Cooling," U.S. Department of Energy Report WSRC-TR-92-142, Revision 1, Westinghouse Savannah River Company, Aiken, SC (1993).

8. ASTM, "Standard Test Methods for Determining Chemical Durability of Nuclear Waste Glasses: The Product Consistency Test (PCT)," ASTM C-1285, (2002).

9. Jantzen, C. M., N. E. Bibler, D. C. Beam, C. L. Crawford and M. A. Pickett, "Characterization of the Defense Waste Processing Facility (DWPF) Environmental Assessment (EA) Glass Standard Reference Material," U.S. Department of Energy Report WSRC-TR-92-346, Revision 1, Westinghouse Savannah River Company, Aiken, SC (1993).

10. Pickenheim, B. R., "22L SRAT Run for Melt Rate Testing - SB6-7,” U.S. Department of Energy Report SRNL-L3100-2009-00184, Revision 0, Savannah River National Laboratory, Aiken, SC (2009).

11. SRNL, "Preparing Batches and Melting in the Dry Feed Melt Rate Furnace," U.S. Department of Energy Report Manual L29, Procedure ITS-00010, Revision 1, Westinghouse Savannah River Company, Aiken, SC (2005).

12. Lambert, D. P., B. R. Pickenheim and D. R. Best, "DWPF SB6 Initial CPC Flowsheet Testing: SB6-1 to SB6-6 4L Tests of SB6-A and SB6-B Simulants," U.S. Department of Energy Report SRNL-STI-2009-00413, Revision 0, Savannah River National Laboratory, Aiken, SC (2009). (In draft) 
13. Bickford, D. F. and C. M. Jantzen, "Devitrification of SRL Defense Waste Glass," in Sci. Basis for Nuclear Waste Management VII, edited by G. L. McVay.

14. Jantzen, C. M., J. B. Picket, K. G. Brown, T. B. Edwards and D. C. Beam, "Process/Product Models for the Defense Waste Processing Facility (DWPF): Part I. Predicting Glass Durability from Composition Using a Thermodynamic Hydration Energy Reaction Model (THERMO)," U.S. Department of Energy Report WSRC-TR-93-672, Revision 1, Westinghouse Savannah River Company, Aiken, SC (1995).

15. Smith, M. E., D. H. Miller and K. M. Fox, "Phase 2 Sludge Batch 5 Melt Rate Furnace Tests," U.S. Department of Energy Report SRNL-PSE-2008-00098, Washington Savannah River Company, Aiken, SC (2008).

16. Miller, D. H., K. M. Fox, B. R. Pickenheim and M. E. Stone, "Melt Rate Furnace Testing for Sludge Batch 5 Frit Optimization," U.S. Department of Energy Report SRNS-STI-2008-00092, Revision 0, Savannah River National Laboratory, Aiken, SC (2008). 
SRNL-STI-2009-00440 REVISION 0

APPENDIX A 
Table A-1. Target and measured compositions of the study glasses, along with their percent differences.

\begin{tabular}{|c|c|c|c|c|c|}
\hline Glass ID & Oxide & $\begin{array}{l}\text { Target } \\
\text { (wt \%) }\end{array}$ & $\begin{array}{c}\text { Measured } \\
(\text { wt \%) }\end{array}$ & $\begin{array}{c}\text { Difference } \\
(w t \%)\end{array}$ & $\begin{array}{c}\text { Percent } \\
\text { Difference }\end{array}$ \\
\hline SB6R1-1 & $\mathrm{Al}_{2} \mathrm{O}_{3}$ & 8.74 & 9.20 & 0.46 & $5.26 \%$ \\
\hline SB6R1-1 & $\mathrm{B}_{2} \mathrm{O}_{3}$ & 4.96 & 4.73 & -0.23 & $-4.57 \%$ \\
\hline SB6R1-1 & $\mathrm{BaO}$ & 0.06 & 0.07 & 0.00 & $5.25 \%$ \\
\hline SB6R1-1 & $\mathrm{CaO}$ & 1.00 & 1.00 & 0.00 & $-0.37 \%$ \\
\hline SB6R1-1 & $\mathrm{Ce}_{2} \mathrm{O}_{3}$ & 0.06 & 0.03 & -0.03 & $-52.96 \%$ \\
\hline SB6R1-1 & $\mathrm{Cr}_{2} \mathrm{O}_{3}$ & 0.12 & 0.10 & -0.02 & $-15.38 \%$ \\
\hline SB6R1-1 & $\mathrm{CuO}$ & 0.03 & 0.03 & 0.00 & $-1.49 \%$ \\
\hline SB6R1-1 & $\mathrm{Fe}_{2} \mathrm{O}_{3}$ & 9.77 & 9.61 & -0.16 & $-1.63 \%$ \\
\hline SB6R1-1 & $\mathrm{K}_{2} \mathrm{O}$ & 0.01 & 0.04 & 0.02 & $205.75 \%$ \\
\hline SB6R1-1 & $\mathrm{La}_{2} \mathrm{O}_{3}$ & 0.03 & 0.03 & 0.00 & $-10.51 \%$ \\
\hline SB6R1-1 & $\mathrm{Li}_{2} \mathrm{O}$ & 4.96 & 4.84 & -0.12 & $-2.47 \%$ \\
\hline SB6R1-1 & $\mathrm{MgO}$ & 0.79 & 0.80 & 0.01 & $0.98 \%$ \\
\hline SB6R1-1 & $\mathrm{MnO}$ & 2.83 & 2.76 & -0.07 & $-2.59 \%$ \\
\hline SB6R1-1 & $\mathrm{Na}_{2} \mathrm{O}$ & 13.95 & 14.45 & 0.50 & $3.56 \%$ \\
\hline SB6R1-1 & $\mathrm{NiO}$ & 1.55 & 1.49 & -0.07 & $-4.44 \%$ \\
\hline SB6R1-1 & $\mathrm{PbO}$ & 0.04 & 0.04 & 0.00 & $0.78 \%$ \\
\hline SB6R1-1 & $\mathrm{SO}_{4}{ }^{2-}$ & 0.29 & 0.47 & 0.18 & $61.31 \%$ \\
\hline SB6R1-1 & $\mathrm{SiO}_{2}$ & 47.73 & 46.01 & -1.72 & $-3.61 \%$ \\
\hline SB6R1-1 & $\mathrm{ThO}_{2}$ & 0.37 & - & - & - \\
\hline SB6R1-1 & $\mathrm{TiO}_{2}$ & 0.01 & 0.02 & 0.01 & $161.13 \%$ \\
\hline SB6R1-1 & $\mathrm{U}_{3} \mathrm{O}_{8}$ & 2.52 & 2.38 & -0.14 & $-5.49 \%$ \\
\hline SB6R1-1 & $\mathrm{ZnO}$ & 0.04 & 0.05 & 0.01 & $29.78 \%$ \\
\hline SB6R1-1 & $\mathrm{ZrO}_{2}$ & 0.13 & 0.15 & 0.03 & $20.32 \%$ \\
\hline SB6R1-1 & Sum & 100.00 & 98.29 & -1.71 & $-1.71 \%$ \\
\hline SB6R1-2 & $\mathrm{Al}_{2} \mathrm{O}_{3}$ & 10.64 & 11.11 & 0.47 & $4.41 \%$ \\
\hline SB6R1-2 & $\mathrm{B}_{2} \mathrm{O}_{3}$ & 4.96 & 4.73 & -0.23 & $-4.57 \%$ \\
\hline SB6R1-2 & $\mathrm{BaO}$ & 0.06 & 0.06 & 0.01 & $9.76 \%$ \\
\hline SB6R1-2 & $\mathrm{CaO}$ & 0.91 & 0.91 & 0.00 & $0.24 \%$ \\
\hline SB6R1-2 & $\mathrm{Ce}_{2} \mathrm{O}_{3}$ & 0.05 & 0.02 & -0.03 & $-54.78 \%$ \\
\hline SB6R1-2 & $\mathrm{Cr}_{2} \mathrm{O}_{3}$ & 0.11 & 0.08 & -0.03 & $-29.06 \%$ \\
\hline SB6R1-2 & $\mathrm{CuO}$ & 0.03 & 0.03 & 0.00 & $-1.22 \%$ \\
\hline SB6R1-2 & $\mathrm{Fe}_{2} \mathrm{O}_{3}$ & 8.85 & 8.77 & -0.09 & $-0.98 \%$ \\
\hline SB6R1-2 & $\mathrm{K}_{2} \mathrm{O}$ & 0.01 & 0.04 & 0.03 & $241.83 \%$ \\
\hline SB6R1-2 & $\mathrm{La}_{2} \mathrm{O}_{3}$ & 0.03 & 0.02 & 0.00 & $-10.95 \%$ \\
\hline SB6R1-2 & $\mathrm{Li}_{2} \mathrm{O}$ & 4.96 & 4.73 & -0.23 & $-4.64 \%$ \\
\hline SB6R1-2 & $\mathrm{MgO}$ & 0.71 & 0.72 & 0.01 & $1.42 \%$ \\
\hline SB6R1-2 & $\mathrm{MnO}$ & 2.57 & 2.50 & -0.07 & $-2.56 \%$ \\
\hline SB6R1-2 & $\mathrm{Na}_{2} \mathrm{O}$ & 13.95 & 14.31 & 0.36 & $2.59 \%$ \\
\hline SB6R1-2 & $\mathrm{NiO}$ & 1.41 & 1.31 & -0.10 & $-7.17 \%$ \\
\hline SB6R1-2 & $\mathrm{PbO}$ & 0.04 & 0.04 & 0.00 & $0.77 \%$ \\
\hline SB6R1-2 & $\mathrm{SO}_{4}{ }^{2-}$ & 0.26 & 0.40 & 0.14 & $52.90 \%$ \\
\hline SB6R1-2 & $\mathrm{SiO}_{2}$ & 47.67 & 45.15 & -2.52 & $-5.29 \%$ \\
\hline SB6R1-2 & $\mathrm{ThO}_{2}$ & 0.33 & - & - & - \\
\hline SB6R1-2 & $\mathrm{TiO}_{2}$ & 0.01 & 0.02 & 0.01 & $155.87 \%$ \\
\hline SB6R1-2 & $\mathrm{U}_{3} \mathrm{O}_{8}$ & 2.29 & 2.18 & -0.10 & $-4.49 \%$ \\
\hline SB6R1-2 & $\mathrm{ZnO}$ & 0.04 & 0.05 & 0.01 & $29.40 \%$ \\
\hline SB6R1-2 & $\mathrm{ZrO}_{2}$ & 0.12 & 0.14 & 0.02 & $19.96 \%$ \\
\hline
\end{tabular}


SRNL-STI-2009-00440 REVISION 0

\begin{tabular}{|c|c|c|c|c|c|}
\hline Glass ID & Oxide & $\begin{array}{l}\text { Target } \\
(\text { wt \%) }\end{array}$ & $\begin{array}{c}\text { Measured } \\
\text { (wt \%) }\end{array}$ & $\begin{array}{c}\text { Difference } \\
\text { (wt \%) }\end{array}$ & $\begin{array}{c}\text { Percent } \\
\text { Difference }\end{array}$ \\
\hline SB6R1-2 & Sum & 100.00 & 97.33 & -2.67 & $-2.67 \%$ \\
\hline SB6R1-3 & $\mathrm{Al}_{2} \mathrm{O}_{3}$ & 7.82 & 8.09 & 0.27 & $3.39 \%$ \\
\hline SB6R1-3 & $\mathrm{B}_{2} \mathrm{O}_{3}$ & 5.28 & 4.80 & -0.48 & $-9.13 \%$ \\
\hline SB6R1-3 & $\mathrm{BaO}$ & 0.05 & 0.05 & 0.00 & $-3.98 \%$ \\
\hline SB6R1-3 & $\mathrm{CaO}$ & 0.85 & 0.83 & -0.02 & $-1.84 \%$ \\
\hline SB6R1-3 & $\mathrm{Ce}_{2} \mathrm{O}_{3}$ & 0.05 & 0.02 & -0.03 & $-59.39 \%$ \\
\hline SB6R1-3 & $\mathrm{Cr}_{2} \mathrm{O}_{3}$ & 0.10 & 0.09 & -0.01 & $-9.02 \%$ \\
\hline SB6R1-3 & $\mathrm{CuO}$ & 0.03 & 0.03 & 0.00 & $-3.71 \%$ \\
\hline SB6R1-3 & $\mathrm{Fe}_{2} \mathrm{O}_{3}$ & 8.25 & 7.71 & -0.54 & $-6.56 \%$ \\
\hline SB6R1-3 & $\mathrm{K}_{2} \mathrm{O}$ & 0.01 & 0.03 & 0.02 & $232.21 \%$ \\
\hline SB6R1-3 & $\mathrm{La}_{2} \mathrm{O}_{3}$ & 0.02 & 0.02 & 0.00 & $-11.85 \%$ \\
\hline SB6R1-3 & $\mathrm{Li}_{2} \mathrm{O}$ & 5.28 & 5.16 & -0.12 & $-2.27 \%$ \\
\hline SB6R1-3 & $\mathrm{MgO}$ & 0.66 & 0.67 & 0.00 & $0.11 \%$ \\
\hline SB6R1-3 & $\mathrm{MnO}$ & 2.39 & 2.32 & -0.07 & $-2.97 \%$ \\
\hline SB6R1-3 & $\mathrm{Na}_{2} \mathrm{O}$ & 14.34 & 14.58 & 0.24 & $1.66 \%$ \\
\hline SB6R1-3 & $\mathrm{NiO}$ & 1.31 & 1.27 & -0.05 & $-3.56 \%$ \\
\hline SB6R1-3 & $\mathrm{PbO}$ & 0.03 & 0.03 & 0.00 & $-8.16 \%$ \\
\hline SB6R1-3 & $\mathrm{SO}_{4}{ }^{2-}$ & 0.24 & 0.31 & 0.06 & $24.91 \%$ \\
\hline SB6R1-3 & $\mathrm{SiO}_{2}$ & 50.68 & 48.15 & -2.53 & $-4.99 \%$ \\
\hline SB6R1-3 & $\mathrm{ThO}_{2}$ & 0.31 & - & - & - \\
\hline SB6R1-3 & $\mathrm{TiO}_{2}$ & 0.01 & 0.02 & 0.01 & $162.24 \%$ \\
\hline SB6R1-3 & $\mathrm{U}_{3} \mathrm{O}_{8}$ & 2.13 & 2.02 & -0.11 & $-5.26 \%$ \\
\hline SB6R1-3 & $\mathrm{ZnO}$ & 0.03 & 0.04 & 0.01 & $29.25 \%$ \\
\hline SB6R1-3 & $\mathrm{ZrO}_{2}$ & 0.11 & 0.13 & 0.02 & $18.74 \%$ \\
\hline SB6R1-3 & Sum & 100.00 & 96.36 & -3.64 & $-3.64 \%$ \\
\hline SB6R1-4 & $\mathrm{Al}_{2} \mathrm{O}_{3}$ & 9.66 & 9.98 & 0.31 & $3.26 \%$ \\
\hline SB6R1-4 & $\mathrm{B}_{2} \mathrm{O}_{3}$ & 4.64 & 4.28 & -0.36 & $-7.70 \%$ \\
\hline SB6R1-4 & $\mathrm{BaO}$ & 0.07 & 0.07 & 0.00 & $2.75 \%$ \\
\hline SB6R1-4 & $\mathrm{CaO}$ & 1.05 & 1.03 & -0.02 & $-1.54 \%$ \\
\hline SB6R1-4 & $\mathrm{Ce}_{2} \mathrm{O}_{3}$ & 0.06 & 0.03 & -0.03 & $-55.50 \%$ \\
\hline SB6R1-4 & $\mathrm{Cr}_{2} \mathrm{O}_{3}$ & 0.13 & 0.10 & -0.03 & $-21.56 \%$ \\
\hline SB6R1-4 & $\mathrm{CuO}$ & 0.03 & 0.03 & 0.00 & $0.44 \%$ \\
\hline SB6R1-4 & $\mathrm{Fe}_{2} \mathrm{O}_{3}$ & 10.19 & 10.05 & -0.14 & $-1.34 \%$ \\
\hline SB6R1-4 & $\mathrm{K}_{2} \mathrm{O}$ & 0.01 & 0.04 & 0.03 & $205.69 \%$ \\
\hline SB6R1-4 & $\mathrm{La}_{2} \mathrm{O}_{3}$ & 0.03 & 0.03 & 0.00 & $-10.60 \%$ \\
\hline SB6R1-4 & $\mathrm{Li}_{2} \mathrm{O}$ & 4.64 & 4.47 & -0.17 & $-3.62 \%$ \\
\hline SB6R1-4 & $\mathrm{MgO}$ & 0.82 & 0.83 & 0.01 & $0.85 \%$ \\
\hline SB6R1-4 & $\mathrm{MnO}$ & 2.96 & 2.84 & -0.12 & $-3.99 \%$ \\
\hline SB6R1-4 & $\mathrm{Na}_{2} \mathrm{O}$ & 15.83 & 16.34 & 0.50 & $3.16 \%$ \\
\hline SB6R1-4 & $\mathrm{NiO}$ & 1.62 & 1.55 & -0.07 & $-4.47 \%$ \\
\hline SB6R1-4 & $\mathrm{PbO}$ & 0.04 & 0.04 & 0.00 & $1.02 \%$ \\
\hline SB6R1-4 & $\mathrm{SO}_{4}{ }^{2-}$ & 0.30 & 0.44 & 0.14 & $44.73 \%$ \\
\hline SB6R1-4 & $\mathrm{SiO}_{2}$ & 44.72 & 41.94 & -2.77 & $-6.20 \%$ \\
\hline SB6R1-4 & $\mathrm{ThO}_{2}$ & 0.38 & - & - & - \\
\hline SB6R1-4 & $\mathrm{TiO}_{2}$ & 0.01 & 0.02 & 0.01 & $118.30 \%$ \\
\hline SB6R1-4 & $\mathrm{U}_{3} \mathrm{O}_{8}$ & 2.63 & 2.49 & -0.14 & $-5.36 \%$ \\
\hline SB6R1-4 & $\mathrm{ZnO}$ & 0.04 & 0.06 & 0.01 & $33.12 \%$ \\
\hline SB6R1-4 & $\mathrm{ZrO}_{2}$ & 0.13 & 0.16 & 0.03 & $21.42 \%$ \\
\hline SB6R1-4 & Sum & 100.00 & 96.81 & -3.19 & $-3.19 \%$ \\
\hline SB6R1-5 & $\mathrm{Al}_{2} \mathrm{O}_{3}$ & 7.82 & 7.79 & -0.04 & $-0.47 \%$ \\
\hline
\end{tabular}


SRNL-STI-2009-00440 REVISION 0

\begin{tabular}{|c|c|c|c|c|c|}
\hline Glass ID & Oxide & $\begin{array}{l}\text { Target } \\
\text { (wt \%) }\end{array}$ & $\begin{array}{c}\text { Measured } \\
\text { (wt \%) }\end{array}$ & $\begin{array}{c}\text { Difference } \\
\text { (wt \%) }\end{array}$ & $\begin{array}{c}\text { Percent } \\
\text { Difference }\end{array}$ \\
\hline SB6R1-5 & $\mathrm{B}_{2} \mathrm{O}_{3}$ & 9.24 & 8.63 & -0.61 & $-6.61 \%$ \\
\hline 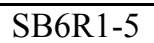 & $\mathrm{BaO}$ & 0.05 & 0.05 & 0.00 & $-7.09 \%$ \\
\hline SB6R1-5 & $\mathrm{CaO}$ & 0.85 & 0.81 & $\begin{array}{l}-0.04 \\
\end{array}$ & $-4.15 \%$ \\
\hline SB6R1-5 & $\mathrm{Ce}_{2} \mathrm{O}_{3}$ & 0.05 & 0.02 & -0.03 & $-59.64 \%$ \\
\hline SB6R1-5 & $\mathrm{Cr}_{2} \mathrm{O}_{3}$ & 0.10 & 0.09 & -0.01 & $-10.03 \%$ \\
\hline SB6R1-5 & $\mathrm{CuO}$ & 0.03 & 0.03 & 0.00 & $7.87 \%$ \\
\hline SB6R1-5 & $\mathrm{Fe}_{2} \mathrm{O}_{3}$ & 8.25 & 7.61 & -0.64 & $-7.77 \%$ \\
\hline SB6R1-5 & $\mathrm{K}_{2} \mathrm{O}$ & 0.01 & 0.03 & 0.02 & $239.38 \%$ \\
\hline SB6R1-5 & $\mathrm{La}_{2} \mathrm{O}_{3}$ & 0.02 & 0.02 & 0.00 & $-10.86 \%$ \\
\hline SB6R1-5 & $\mathrm{Li}_{2} \mathrm{O}$ & 4.62 & 4.47 & -0.15 & $-3.20 \%$ \\
\hline SB6R1-5 & $\mathrm{MgO}$ & 0.66 & 0.64 & -0.02 & $-3.13 \%$ \\
\hline SB6R1-5 & $\mathrm{MnO}$ & 2.39 & 2.24 & -0.15 & $-6.20 \%$ \\
\hline SB6R1-5 & $\mathrm{Na}_{2} \mathrm{O}$ & 14.34 & 14.18 & -0.17 & $-1.17 \%$ \\
\hline SB6R1-5 & $\mathrm{NiO}$ & 1.31 & 1.26 & -0.06 & $-4.24 \%$ \\
\hline SB6R1-5 & $\mathrm{PbO}$ & 0.03 & 0.03 & 0.00 & $3.03 \%$ \\
\hline SB6R1-5 & $\mathrm{SO}_{4}{ }^{2-}$ & 0.24 & 0.36 & 0.11 & $45.72 \%$ \\
\hline SB6R1-5 & $\mathrm{SiO}_{2}$ & 47.38 & 44.73 & -2.65 & $-5.59 \%$ \\
\hline SB6R1-5 & $\mathrm{ThO}_{2}$ & 0.31 & - & - & - \\
\hline SB6R1-5 & $\mathrm{TiO}_{2}$ & 0.01 & 0.02 & 0.01 & $143.19 \%$ \\
\hline SB6R1-5 & $\mathrm{U}_{3} \mathrm{O}_{8}$ & 2.13 & 1.97 & -0.16 & $-7.47 \%$ \\
\hline SB6R1-5 & $\mathrm{ZnO}$ & 0.03 & 0.04 & 0.01 & $31.48 \%$ \\
\hline SB6R1-5 & $\mathrm{ZrO}_{2}$ & 0.11 & 0.12 & 0.02 & $15.37 \%$ \\
\hline SB6R1-5 & Sum & 100.00 & 95.15 & -4.85 & $-4.85 \%$ \\
\hline SB6R1-6 & $\mathrm{Al}_{2} \mathrm{O}_{3}$ & 9.66 & 9.79 & 0.13 & $1.30 \%$ \\
\hline SB6R1-6 & $\mathrm{B}_{2} \mathrm{O}_{3}$ & 8.12 & 7.79 & -0.33 & $-4.03 \%$ \\
\hline SB6R1-6 & $\mathrm{BaO}$ & 0.07 & 0.08 & 0.01 & $16.69 \%$ \\
\hline SB6R1-6 & $\mathrm{CaO}$ & 1.05 & 1.00 & -0.04 & $-4.08 \%$ \\
\hline SB6R1-6 & $\mathrm{Ce}_{2} \mathrm{O}_{3}$ & 0.06 & 0.03 & -0.03 & $-54.50 \%$ \\
\hline SB6R1-6 & $\mathrm{Cr}_{2} \mathrm{O}_{3}$ & 0.13 & 0.10 & -0.02 & $-16.07 \%$ \\
\hline SB6R1-6 & $\mathrm{CuO}$ & 0.03 & 0.03 & 0.00 & $-1.81 \%$ \\
\hline SB6R1-6 & $\mathrm{Fe}_{2} \mathrm{O}_{3}$ & 10.19 & 9.52 & -0.67 & $-6.54 \%$ \\
\hline SB6R1-6 & $\mathrm{K}_{2} \mathrm{O}$ & 0.01 & 0.04 & 0.03 & $201.82 \%$ \\
\hline SB6R1-6 & $\mathrm{La}_{2} \mathrm{O}_{3}$ & 0.03 & 0.02 & 0.00 & $-15.01 \%$ \\
\hline SB6R1-6 & $\mathrm{Li}_{2} \mathrm{O}$ & 4.06 & 4.00 & -0.06 & $-1.50 \%$ \\
\hline SB6R1-6 & $\mathrm{MgO}$ & 0.82 & 0.81 & -0.01 & $-1.78 \%$ \\
\hline SB6R1-6 & $\mathrm{MnO}$ & 2.96 & 2.77 & -0.18 & $-6.18 \%$ \\
\hline SB6R1-6 & $\mathrm{Na}_{2} \mathrm{O}$ & 15.83 & 16.07 & 0.23 & $1.45 \%$ \\
\hline SB6R1-6 & $\mathrm{NiO}$ & 1.62 & 1.47 & -0.15 & $-9.17 \%$ \\
\hline SB6R1-6 & $\mathrm{PbO}$ & 0.04 & 0.04 & 0.00 & $-3.90 \%$ \\
\hline SB6R1-6 & $\mathrm{SO}_{4}{ }^{2-}$ & 0.30 & 0.42 & 0.12 & $38.79 \%$ \\
\hline SB6R1-6 & $\mathrm{SiO}_{2}$ & 41.82 & 40.23 & -1.59 & $-3.79 \%$ \\
\hline SB6R1-6 & $\mathrm{ThO}_{2}$ & 0.38 & - & - & - \\
\hline SB6R1-6 & $\mathrm{TiO}_{2}$ & 0.01 & 0.02 & 0.01 & $158.35 \%$ \\
\hline SB6R1-6 & $\mathrm{U}_{3} \mathrm{O}_{8}$ & 2.63 & 2.49 & -0.14 & $-5.36 \%$ \\
\hline SB6R1-6 & $\mathrm{ZnO}$ & 0.04 & 0.05 & 0.01 & $22.02 \%$ \\
\hline SB6R1-6 & $\mathrm{ZrO}_{2}$ & 0.13 & 0.16 & 0.02 & $17.38 \%$ \\
\hline SB6R1-6 & Sum & 100.00 & 96.94 & -3.06 & $-3.06 \%$ \\
\hline SB6R1-7 & $\mathrm{Al}_{2} \mathrm{O}_{3}$ & 10.64 & 10.74 & 0.09 & $0.86 \%$ \\
\hline SB6R1-7 & $\mathrm{B}_{2} \mathrm{O}_{3}$ & 4.96 & 4.60 & -0.36 & $-7.17 \%$ \\
\hline SB6R1-7 & $\mathrm{BaO}$ & 0.05 & 0.06 & 0.01 & $13.32 \%$ \\
\hline
\end{tabular}


SRNL-STI-2009-00440 REVISION 0

\begin{tabular}{|c|c|c|c|c|c|}
\hline Glass ID & Oxide & $\begin{array}{l}\text { Target } \\
(\text { wt \%) }\end{array}$ & $\begin{array}{c}\text { Measured } \\
\text { (wt \%) }\end{array}$ & $\begin{array}{c}\text { Difference } \\
\text { (wt \%) }\end{array}$ & $\begin{array}{c}\text { Percent } \\
\text { Difference }\end{array}$ \\
\hline SB6R1-7 & $\mathrm{CaO}$ & 0.85 & 0.82 & -0.04 & $-4.13 \%$ \\
\hline SB6R1-7 & $\mathrm{Ce}_{2} \mathrm{O}_{3}$ & 0.05 & 0.02 & -0.03 & $-57.94 \%$ \\
\hline SB6R1-7 & $\mathrm{Cr}_{2} \mathrm{O}_{3}$ & 0.10 & 0.09 & -0.01 & $-11.62 \%$ \\
\hline SB6R1-7 & $\mathrm{CuO}$ & 0.03 & 0.03 & 0.00 & $1.64 \%$ \\
\hline SB6R1-7 & $\mathrm{Fe}_{2} \mathrm{O}_{3}$ & 8.30 & 7.88 & -0.42 & $-5.11 \%$ \\
\hline SB6R1-7 & $\mathrm{K}_{2} \mathrm{O}$ & 0.01 & 0.04 & 0.03 & $257.33 \%$ \\
\hline SB6R1-7 & $\mathrm{La}_{2} \mathrm{O}_{3}$ & 0.02 & 0.02 & 0.00 & $-10.46 \%$ \\
\hline SB6R1-7 & $\mathrm{Li}_{2} \mathrm{O}$ & 4.96 & 4.75 & -0.21 & $-4.20 \%$ \\
\hline SB6R1-7 & $\mathrm{MgO}$ & 0.67 & 0.66 & -0.01 & $-1.79 \%$ \\
\hline SB6R1-7 & $\mathrm{MnO}$ & 2.41 & 2.28 & -0.13 & $-5.21 \%$ \\
\hline SB6R1-7 & $\mathrm{Na}_{2} \mathrm{O}$ & 15.09 & 15.12 & 0.03 & $0.21 \%$ \\
\hline SB6R1-7 & $\mathrm{NiO}$ & 1.32 & 1.22 & -0.10 & $-7.75 \%$ \\
\hline SB6R1-7 & $\mathrm{PbO}$ & 0.03 & 0.03 & 0.00 & $2.99 \%$ \\
\hline SB6R1-7 & $\mathrm{SO}_{4}{ }^{2-}$ & 0.25 & 0.36 & 0.12 & $47.20 \%$ \\
\hline SB6R1-7 & $\mathrm{SiO}_{2}$ & 47.64 & 44.08 & -3.56 & $-7.46 \%$ \\
\hline SB6R1-7 & $\mathrm{ThO}_{2}$ & 0.31 & - & - & - \\
\hline SB6R1-7 & $\mathrm{TiO}_{2}$ & 0.01 & 0.02 & 0.01 & $170.34 \%$ \\
\hline SB6R1-7 & $\mathrm{U}_{3} \mathrm{O}_{8}$ & 2.14 & 2.01 & -0.14 & $-6.43 \%$ \\
\hline SB6R1-7 & $\mathrm{ZnO}$ & 0.03 & 0.04 & 0.01 & $25.83 \%$ \\
\hline SB6R1-7 & $\mathrm{ZrO}_{2}$ & 0.11 & 0.13 & 0.02 & $17.09 \%$ \\
\hline SB6R1-7 & Sum & 100.00 & 95.00 & -5.00 & $-5.00 \%$ \\
\hline SB6R1-8 & $\mathrm{Al}_{2} \mathrm{O}_{3}$ & 8.74 & 9.07 & 0.33 & $3.75 \%$ \\
\hline SB6R1-8 & $\mathrm{B}_{2} \mathrm{O}_{3}$ & 4.96 & 4.64 & -0.32 & $-6.52 \%$ \\
\hline SB6R1-8 & $\mathrm{BaO}$ & 0.06 & 0.06 & 0.00 & $3.60 \%$ \\
\hline SB6R1-8 & $\mathrm{CaO}$ & 0.89 & 0.88 & -0.01 & $-1.26 \%$ \\
\hline SB6R1-8 & $\mathrm{Ce}_{2} \mathrm{O}_{3}$ & 0.05 & 0.02 & -0.03 & $-57.12 \%$ \\
\hline SB6R1-8 & $\mathrm{Cr}_{2} \mathrm{O}_{3}$ & 0.11 & 0.09 & -0.02 & $-14.53 \%$ \\
\hline SB6R1-8 & $\mathrm{CuO}$ & 0.03 & 0.03 & 0.00 & $11.44 \%$ \\
\hline SB6R1-8 & $\mathrm{Fe}_{2} \mathrm{O}_{3}$ & 8.67 & 8.24 & -0.43 & $-5.00 \%$ \\
\hline SB6R1-8 & $\mathrm{K}_{2} \mathrm{O}$ & 0.01 & 0.04 & 0.03 & $246.78 \%$ \\
\hline SB6R1-8 & $\mathrm{La}_{2} \mathrm{O}_{3}$ & 0.02 & 0.02 & 0.00 & $-13.78 \%$ \\
\hline SB6R1-8 & $\mathrm{Li}_{2} \mathrm{O}$ & 4.96 & 4.92 & -0.04 & $-0.74 \%$ \\
\hline SB6R1-8 & $\mathrm{MgO}$ & 0.70 & 0.71 & 0.01 & $1.43 \%$ \\
\hline SB6R1-8 & $\mathrm{MnO}$ & 2.52 & 2.41 & -0.10 & $-4.09 \%$ \\
\hline SB6R1-8 & $\mathrm{Na}_{2} \mathrm{O}$ & 16.23 & 16.61 & 0.38 & $2.32 \%$ \\
\hline SB6R1-8 & $\mathrm{NiO}$ & 1.38 & 1.30 & -0.08 & $-6.13 \%$ \\
\hline SB6R1-8 & $\mathrm{PbO}$ & 0.04 & 0.03 & 0.00 & $-5.32 \%$ \\
\hline SB6R1-8 & $\mathrm{SO}_{4}{ }^{2-}$ & 0.26 & 0.37 & 0.11 & $44.47 \%$ \\
\hline SB6R1-8 & $\mathrm{SiO}_{2}$ & 47.66 & 45.37 & -2.29 & $-4.81 \%$ \\
\hline SB6R1-8 & $\mathrm{ThO}_{2}$ & 0.33 & - & - & - \\
\hline SB6R1-8 & $\mathrm{TiO}_{2}$ & 0.01 & 0.02 & 0.01 & $191.87 \%$ \\
\hline SB6R1-8 & $\mathrm{U}_{3} \mathrm{O}_{8}$ & 2.24 & 2.11 & -0.13 & $-5.64 \%$ \\
\hline SB6R1-8 & $\mathrm{ZnO}$ & 0.04 & 0.05 & 0.01 & $37.78 \%$ \\
\hline SB6R1-8 & $\mathrm{ZrO}_{2}$ & 0.11 & 0.14 & 0.02 & $21.30 \%$ \\
\hline SB6R1-8 & Sum & 100.00 & 97.12 & -2.88 & $-2.88 \%$ \\
\hline SB6R1-9 & $\mathrm{Al}_{2} \mathrm{O}_{3}$ & 10.64 & 11.09 & 0.45 & $4.23 \%$ \\
\hline SB6R1-9 & $\mathrm{B}_{2} \mathrm{O}_{3}$ & 4.96 & 4.70 & -0.26 & $-5.22 \%$ \\
\hline SB6R1-9 & $\mathrm{BaO}$ & 0.05 & 0.05 & 0.00 & $4.80 \%$ \\
\hline SB6R1-9 & $\mathrm{CaO}$ & 0.80 & 0.81 & 0.01 & $1.61 \%$ \\
\hline SB6R1-9 & $\mathrm{Ce}_{2} \mathrm{O}_{3}$ & 0.04 & 0.02 & -0.02 & $-55.22 \%$ \\
\hline
\end{tabular}


SRNL-STI-2009-00440 REVISION 0

\begin{tabular}{|c|c|c|c|c|c|}
\hline Glass ID & Oxide & $\begin{array}{l}\text { Target } \\
\text { (wt \%) }\end{array}$ & $\begin{array}{c}\text { Measured } \\
\text { (wt \%) }\end{array}$ & $\begin{array}{c}\text { Difference } \\
\text { (wt \%) }\end{array}$ & $\begin{array}{c}\text { Percent } \\
\text { Difference }\end{array}$ \\
\hline SB6R1-9 & $\overline{\mathrm{Cr}_{2} \mathrm{O}_{3}}$ & 0.10 & 0.09 & -0.01 & $-9.65 \%$ \\
\hline SB6R1-9 & $\mathrm{CuO}$ & 0.03 & 0.03 & 0.00 & $8.35 \%$ \\
\hline SB6R1-9 & $\mathrm{Fe}_{2} \mathrm{O}_{3}$ & 7.75 & 7.55 & -0.20 & $-2.63 \%$ \\
\hline SB6R1-9 & $\mathrm{K}_{2} \mathrm{O}$ & 0.01 & 0.03 & 0.02 & $255.95 \%$ \\
\hline SB6R1-9 & $\mathrm{La}_{2} \mathrm{O}_{3}$ & 0.02 & 0.02 & 0.00 & $-10.97 \%$ \\
\hline SB6R1-9 & $\mathrm{Li}_{2} \mathrm{O}$ & 4.96 & 4.92 & -0.04 & $-0.74 \%$ \\
\hline SB6R1-9 & $\mathrm{MgO}$ & 0.63 & 0.64 & 0.01 & $2.25 \%$ \\
\hline SB6R1-9 & $\mathrm{MnO}$ & 2.25 & 2.19 & -0.06 & $-2.51 \%$ \\
\hline SB6R1-9 & $\mathrm{Na}_{2} \mathrm{O}$ & 16.23 & 17.01 & 0.78 & $4.82 \%$ \\
\hline SB6R1-9 & $\mathrm{NiO}$ & 1.23 & 1.19 & -0.05 & $-3.68 \%$ \\
\hline SB6R1-9 & $\mathrm{PbO}$ & 0.03 & 0.03 & 0.00 & $0.76 \%$ \\
\hline SB6R1-9 & $\mathrm{SO}_{4}{ }^{2-}$ & 0.23 & 0.34 & 0.11 & $45.90 \%$ \\
\hline SB6R1-9 & $\mathrm{SiO}_{2}$ & 47.61 & 45.15 & -2.45 & $-5.15 \%$ \\
\hline SB6R1-9 & $\mathrm{ThO}_{2}$ & 0.29 & - & - & - \\
\hline SB6R1-9 & $\mathrm{TiO}_{2}$ & 0.01 & 0.03 & 0.03 & $442.16 \%$ \\
\hline SB6R1-9 & $\mathrm{U}_{3} \mathrm{O}_{8}$ & 2.00 & 1.85 & -0.15 & $-7.46 \%$ \\
\hline SB6R1-9 & $\mathrm{ZnO}$ & 0.03 & 0.04 & 0.01 & $35.14 \%$ \\
\hline SB6R1-9 & $\mathrm{ZrO}_{2}$ & 0.10 & 0.12 & 0.02 & $20.60 \%$ \\
\hline SB6R1-9 & Sum & 100.00 & 97.92 & -2.08 & $-2.08 \%$ \\
\hline
\end{tabular}




\section{Distribution:}

C. J. Bannochie, 773-42A

A. B. Barnes, 999-W

A. L. Billings, 999-W

J. M. Bricker, 704-27S

A. S. Choi, 773-42A

D. A. Crowley, 773-43A

T. B. Edwards, 999-W

T. L. Fellinger, 704-26S

K. M. Fox, 999-W

S. D. Fink, 773-A

C. W. Gardner, 773-A

B. J. Giddings, 786-5A

J. M. Gillam, 766-H

B. A. Hamm, 766-H

C. C. Herman, 999-W

E. W. Holtzscheiter, 704-15S

J. F. Iaukea, 704-30S

M. T. Keefer, 766-H

D. D. Larsen, 766-H

P. L. Lee, 773-42A

S. L. Marra, 773-A

D. J. McCabe, 773-42A

R. T. McNew, 704-27S

D. H. Miller, 999-W

J. D. Newell, 999-W

J. E. Occhipinti, 704-S

D. K. Peeler, 999-W

F. M. Pennebaker, 773-42A

F. C. Raszewski, 999-W

J. W. Ray, 704-S

H. B. Shah, 766-H

D. C. Sherburne, 704-S

M. E. Stone, 999-W 